DOI: $10.19195 / 0137-1134.114 .19$

\author{
ROMAN HAUSER \\ rhauser@amu.edu.pl \\ MARTA SZUSTKIEWICZ \\ Naczelny Sąd Administracyjny \\ mszustkiewicz@nsa.gov.pl
}

Uniwersytet im. Adama Mickiewicza w Poznaniu

\title{
PRZEPISY OGRANICZAJĄCE KONKURENCJĘ W AKTACH PRAWA MIEJSCOWEGO
}

\begin{abstract}
Abstrakt: Zgodnie z Konstytucją RP organy samorządu terytorialnego są uprawnione do wydawania aktów prawa miejscowego między innymi w sprawach własnych, to jest w sprawach dotyczących zaspokajania bieżących potrzeb mieszkańców gmin, na przykład utrzymanie czystości, dostarczanie wody, organizowanie transportu lokalnego. Z uwagi na szczególną (monopolistyczną lub dominującą) pozycję jednostek samorządu terytorialnego często w tych sprawach dochodzi do naruszeń zasad wolnorynkowych. Opracowanie przedstawia typowe przypadki nadużyć rynkowych i zakłóceń wolnej konkurencji, których źródłem był wadliwy przepis prawa miejscowego, bądź to z powodu niezgodności z ustawą o ochronie konkurencji i konsumentów, bądź też z innym przepisem prawa powszechnie obowiązującego, na przykład ustawą o utrzymaniu czystości i porządku w gminach. Skutki takich przepisów obciążają konsumentów (mieszkańców gmin), którzy nie mając możliwości wyboru - ponoszą dotkliwe (w tym finansowe) konsekwencje takich wadliwych regulacji.
\end{abstract}

Słowa kluczowe: prawo miejscowe, samorząd terytorialny, praktyki ograniczające konkurencję, Prezes Urzędu Ochrony Konkurencji i Konsumentów, Konstytucja, legislacja

\section{SZCZEGÓLNA ROLA GMINY W LOKALNYM PROCESIE PRAWOTWÓRCZYM}

Stanowienie przepisów lokalnych jest jedną z fundamentalnych cech kształtujących samorząd terytorialny. Organy samorządu terytorialnego dysponują znacznym stopniem niezależności przy ich wydawaniu, co stanowi wyraz ich samodzielności, ale też wymaga konieczności wszechstronnej oceny legalności tworzonych przepisów lokalnych.

W obecnym stanie prawnym kompetencje prawodawcze organów samorządu terytorialnego mają swoje umocowania w Konstytucji oraz ustawach szczegóło- 
wych, które przyznają prawo uchwalania przepisów odpowiadających specyfice stosunków społecznych występujących na danym obszarze w obrębie danej wspólnoty mieszkańców ${ }^{1}$. Regulacje konstytucyjne dotyczące aktów prawa miejscowego są szczątkowe, Konstytucja reguluje tę materię jedynie w dwóch przepisach, to jest art. 87 ust. 2 i art. 94, które pozwalają na wyodrębnienie wyłącznie podstawowych kryteriów służących zdefiniowaniu pojęcia prawa miejscowego ${ }^{2}$. Konstytucja wskazuje podmioty uprawnione do stanowienia prawa bez określenia form tego prawa, co prowadzi do „rozchwiania” koncepcji źródeł prawa ${ }^{3}$ i wpływa negatywnie na proces stanowienia prawa oraz powoduje, że relacje między aktami wydawanym przez poszczególne organy są nieczytelne i powodują trudności interpretacyjne oraz spory doktrynalne ${ }^{4}$. Akty prawa miejscowego mają moc obowiązującą w stosunku do określonych ogólnie kategorii podmiotów, bez względu na więź prawną i organizacyjną łączącą ich z prawodawcą. Mogą zatem regulować postępowanie wszystkich kategorii adresatów, w tym zewnętrznych, wobec administracji ${ }^{5}$.

Normatywne podstawy stanowienia aktów prawa miejscowego zawiera art. 94 Konstytucji, zgodnie z którym zarówno organy samorządu terytorialnego, jak i terenowe organy administracji rządowej mają kompetencje prawodawcze „,na podstawie i w granicach upoważnień zawartych w ustawie". Ta reguła wskazuje, że obligatoryjnym warunkiem wydania aktu prawa miejscowego jest istnienie ustawowej normy upoważniającej do takiego działania, co wynika z konstytucyjnej zasady prymatu ustawy, zasady praworządności (legalizmu) oraz zasady hierarchicznej budowy systemu źródeł prawa. Konkretyzacja zawartego w art. 94 Konstytucji określenia „organ samorządu terytorialnego" nastąpiła w ustawach ustrojowych, regulujących zasady działania poszczególnych samorządów, to jest ustawie z dnia 8 marca 1990 roku o samorządzie gminnym ${ }^{6}$, ustawie z dnia 5 czerwca 1998 roku o samorządzie powiatowym ${ }^{7}$ oraz ustawie z dnia 5 czerwca 1998 roku o samorządzie województwa ${ }^{8}$. W każdej z tych ustaw odrębnie i nieco odmiennie uregulowano kwestię stanowienia oraz zakresu przedmiotowego aktów prawa miejscowego 9 .

1 M. Szreniawska, System kontroli aktów prawa miejscowego, [w:] Samorząd terytorialny w Polsce a sadowa kontrola administracji, red. B. Dolnicki, J.P. Tarno, Warszawa 2012.

2 D. Dąbek, Prawo miejscowe, Warszawa 2015, s. 61.

3 A. Bałaban, Otwarty czy zamknięty system źródet prawa, [w:] Mała konstytucja w procesie przemian ustrojowych $w$ Polsce, red. M. Kruk, Warszawa 1993, s. 157.

${ }^{4}$ Pogląd, zgodnie z którym Konstytucja nie zamyka kręgu organów upoważnionych do wydawania aktów prawa miejscowego, prezentuje J. Boć, Konstytucje Rzeczypospolitej oraz komentarz do Konstytucji RP z 1997 roku, Wrocław 1998, s. 167; odmiennie J. Świątkiewicz, Prawo miejscowe pod rządem Konstytucji z 1997 r., „Przegląd Legislacyjny” 2000, nr 1, s. 84.

5 D. Dąbek, Sądowa kontrola aktów prawa miejscowego - aspekt materialnoprawny, ,Zeszyty Naukowe Sądownictwa Administracyjnego" 2013, nr 3, s. 84.

6 Dz.U. z 2016 r. poz. 446 ze zm. (dalej: u.s.g.).

7 Dz.U. z 2016 r. poz. 814 ze zm. (dalej: u.s.p.).

8 Dz.U. z 2015 r. poz. 1392 ze zm. (dalej: u.s.w.).

9 P. Mijal, Cechy charakterystyczne aktów prawa miejscowego na tle orzecznictwa sądów administracyjnych, ZNSA 2007, nr 5-6, s. 47. 
Jak wskazuje orzecznictwo sądów administracyjnych:

nie ma ustawowej definicji „aktu prawa miejscowego”, lecz nie ulega wątpliwości, iż za prawo miejscowe mogą być uznane jedynie przepisy mające charakter norm prawnych. Akty prawa miejscowego są źródłami prawa, a więc muszą posiadać cechy ogólności (generalności) i abstrakcyjności. Charakter generalny posiadają normy, które określają adresata poprzez wskazanie jego cech, nie zaś poprzez wymienienie ich z imienia (nazwy). Abstrakcyjność normy polega na tym, że jej dyspozycja określająca postępowanie adresata ma zastosowanie w wielu, powtarzalnych okolicznościach, nie zaś w jednej konkretnej sytuacji ${ }^{10}$.

Organowi samorządu terytorialnego przysługuje szczególny status w lokalnym procesie stanowienia prawa. Podejmuje on inicjatywę prawodawczą, ma bezpośredni wpływ na treść aktu lub przesądza o wystąpieniu zaniechania prawodawczego, gdy konieczność wydania aktu normatywnego przewiduje przepis prawa, a organ nie wykonuje tego obowiązku. Szczególny status organu powoduje, że może on wpływać na stan gospodarki, na przykład decydować o podjęciu działalności gospodarczej ${ }^{11}$ lub za pomocą odpowiednich regulacji prawnych przyznać sobie uprzywilejowaną pozycję albo usunąc $\mathrm{z}$ rynku innych przedsiębiorców ${ }^{12}$. Istotna jest zatem ocena prawodawczych działań gminy z punktu widzenia zasad wolnej konkurencji. Przepisy u.s.g. nałożyły na gminy obowiązek zaspokajania zborowych potrzeb wspólnoty, które zgodnie z art. 7 ust. 1 dotyczą między innymi spraw lokalnego transportu, utrzymania czystości czy cmentarzy komunalnych. Gminy w przepisach dotyczących tych spraw często wprowadzają regulacje naruszające ustawę antymonopolową ${ }^{13}$.

Zarówno organy państwa, jak i władze lokalne powinny dążyć do tworzenia regulacji korzystnych dla konsumentów (mieszkańców gmin) ${ }^{14}$. Prawo antymonopolowe ma na celu ochronę interesu ogólnospołecznego, który może być zagrożony wskutek niekorzystnych zjawisk rynkowych, spowodowanych między innymi przepisami prawa miejscowego. Konsumenci oraz przedsiębiorcy mają zapewnioną ochronę przed skutkami tych niekorzystnych przepisów. Ochrona ta dokonywana jest przez Prezesa Urzędu Ochrony Konkurencji i Konsumentów i Sąd Ochrony Konkurencji i Konsumentów — pod względem zgodności z regułami wolnej konkurencji oraz przez sądy administracyjne — pod względem zgodności z prawem.

10 Wyrok NSA z dnia 18 lipca 2006 r., I OSK 669/06, CBOSA.

11 M. Szydło, Monopol gminy w świetle regut funkcjonowania wspólnotowego rynku w Unii Europejskiej, „Samorząd Terytorialny” 2005, nr 7-8, s. 39.

12 T. Skoczny, Dopuszczalność działalności gospodarczej gmin, „Samorząd Terytorialny” 1991, nr 3, s. 6

13 Ustawa z dnia 16 lutego 2007 r. o ochronie konkurencji i konsumentów (Dz.U. Nr 50, poz. 331 ze zm.; dalej: ustawa antymonopolowa).

14 H. Bylka, [w:] Konkurencja w gospodarce współczesnej, red. C. Banasiński, E. Stawicki, Warszawa 2007, s. 186. 
W 2017 roku minęło dwadzieścia lat obowiązywania Konstytucji, która powierzyła samorządom uprawnienie do tworzenia prawa miejscowego, oraz ponad ćwierćwiecze funkcjonowania gospodarki wolnorynkowej. Mimo upływu lat, bogatego orzecznictwa sądów powszechnych i administracyjnych poziom przepisów gminnych nadal może budzić pewne wątpliwości pod względem ich zgodności $\mathrm{z}$ prawem, w tym prawem antymonopolowym.

\section{NARUSZENIA PRAWA ANTYMONOPOLOWEGO W AKTACH PRAWA MIEJSCOWEGO}

\subsection{UWAGI OGÓLNE}

Najliczniejsze przypadki regulacji prawa miejscowego naruszających zasady wolnej konkurencji występują w przepisach wydawanych na podstawie upoważnień zawartych w ustawach odrębnych w tak zwanych sprawach własnych. Kategoria zadań własnych rozumianych jako sprawy, których celem jest zaspokajanie zbiorowych potrzeb mieszkańców gminy, to zadania w sposób „,naturalny” związane $z$ samorządem gminnym ${ }^{15}$. Jest oczywiste, że w trakcie wykonywania nałożonych prawem zadań gmina staje się uczestnikiem życia gospodarczego. Działalność gospodarcza gmin skupia się na zadaniach o charakterze użyteczności publicznej, mających na celu bieżące i nieprzerwane zaspokajanie zbiorowych potrzeb ludności ${ }^{16}$. Konkurencja na tych rynkach, może być wykluczona lub zniekształcona $\mathrm{z}$ racji szczególnej funkcji, jaką gminy na nich pełnią ${ }^{17}$. Zgodnie z utrwalonymi poglądami doktryny do uznania określonego działania za przejaw praktyki ograniczającej konkurencję nie jest konieczne, aby to działanie wywołało skutki na rynku, wystarczy jedynie możliwość wystąpienia negatywnych zjawisk na rynku ${ }^{18}$.

Odpowiednie i zgodne $\mathrm{z}$ prawem zredagowanie przepisów prawa miejscowego ma przeciwdziałać dyskryminacyjnym działaniom gminy — podmiotu silniejszego, najczęściej o pozycji dominującej, której działaniami dotknięci są wszyscy mieszkańcy gminy. Ochrona konsumentów przed antykonkurencyjnymi działaniami gmin jest szczególnie ważna, jako że większość wydatków na usługi o charakterze użyteczności publicznej ma istotne znaczenie w budżetach całej lokalnej społeczności; wpływają bowiem na ceny wody, biletów za przejazd ko-

15 K. Jaroszyński, [w:] Ustawa o samorzadzie gminnym. Komentarz, red. R. Hauser, Z. Niewiadomski, Warszawa 2014, s. 74.

16 M. Kulesza, Gospodarka komunalna - podstawy i mechanizmy prawne, „Samorząd Terytorialny" 2012, nr 7-8, s. 7.

17 Z. Jurczyk, Zakres interwencji organu antymonopolowego w działalność gospodarcza gmin, Warszawa 2011, s. 2.

18 C. Banasiński, E. Piontek, Ustawa o ochronie konkurencji i konsumentów. Komentarz, Warszawa 2009. 
munikacją zbiorową, opłaty za wywóz odpadów. Gminy — jako organy władzy publicznej — zobowiązane są na mocy art. 7 Konstytucji działać na podstawie i w granicach prawa. Oznacza to, że wszelkie akty prawne i czynności organów gminy, również wydawanie przepisów prawnych, muszą być zgodne z obowiązującym w Polsce ustawodawstwem, w tym z ustawą antymonopolową. W kwestii odpowiedzialności gminy za prowadzoną gospodarkę komunalną wypowiedział się Sąd Najwyższy w wyroku z dnia 20 listopada 2008 roku $^{19}$ oraz Trybunał Konstytucyjny w uchwale $z$ dnia 27 września 1994 roku $^{20}$. Trybunał, rozpoznając pytanie prawne Prezesa NSA, uznał, że możliwe jest ustanowienie przez ustawodawcę kontroli lub nadzoru nad określonymi formami działalności komunalnej gminy, wykonywanego w innym trybie i przez organy działające za pomocą sobie właściwych środków prawnych. Sąd Najwyższy przesądził, że gminy odpowiadają za wydawane akty prawa miejscowego pod względem wpływu na konkurencję na rynku (a nie pod kątem ich legalności, którą oceniają sądy administracyjne). Jednostka samorządu terytorialnego ma obowiązek uwzględnić w swojej działalności zakazy wynikające z ustawy antymonopolowej. Treść tych aktów może stanowić podstawę zarzutu naruszenia prawa konkurencji.

\subsection{PRZYKŁADY NAJCZESTSZYCH KOMUNALNYCH PRAKTYK NARUSZAJĄCYCH KONKURENCJĘ}

Antykonkurencyjne działania gmin ujawniają się najczęściej na kilku obszarach działalności komunalnej, to jest na rynku zbierania i składowania odpadów stałych, rynku dostaw wody i odprowadzania ścieków oraz rynku organizowania transportu lokalnego. W tych przypadkach działania gminy prowadzone na podstawie własnych przepisów miejscowych często skutkują naruszeniem reguł konkurencji przez nadużycie pozycji dominującej lub zawarcie antykonkurencyjnego porozumienia.

\subsubsection{RYNEK ZBIERANIA I SKŁADOWANIA ODPADÓW}

To rynek szczególnie podatny na wszelkie antykonkurencyjne działania gmin ze względu na ich szczególną pozycję na tym rynku ${ }^{21}$. Gmina ma monopol prawny w organizowaniu utrzymania czystości i porządku wynikający z ustawy z dnia 13 września 1996 roku o utrzymaniu czystości i porządku w gminach ${ }^{22}$. Przepis art. 4 ust. 1 ustawy o utrzymaniu czystości stanowi podstawę prawną do korzystania przez gminę z instrumentów o charakterze władczym, to jest wydania odpowiedniego regulaminu. Przepis ten w brzmieniu obecnie obowiązującym sta-

19 Wyrok Sądu Najwyższego z dnia 20 listopada 2008 r., III SK 12/08, LEX nr 510142.

20 Uchwała TK z dnia 27 września 1994 r. w sprawie powszechnie obowiązującej wykładni art. 85 i 87 ustawy o samorządzie terytorialnym (Dz.U. Nr 113, poz. 550).

21 Z. Jurczyk, op. cit., s. 14.

22 Dz.U. z 2016 r. poz. 250 ze zm. (dalej: ustawa o utrzymaniu czystości). 
nowi, że rada gminy po zasięgnięciu opinii państwowego powiatowego inspektora sanitarnego uchwala regulamin utrzymania czystości i porządku na terenie gminy, który jest aktem prawa miejscowego. W ten sposób jednoznacznie przesądzono, że regulamin utrzymania czystości i porządku w gminie jest aktem prawa miejscowego, orzecznictwo sądów administracyjnych było bowiem do nowelizacji ustawy o utrzymaniu czystości rozbieżne w zakresie podstawy prawnej regulaminu oraz statusu tego $\mathrm{aktu}^{23}$. Jak wynika $\mathrm{z}$ ugruntowanego orzecznictwa sądów administracyjnych, regulacja przepisu art. 4 ust. 2 ustawy o utrzymaniu czystości ma charakter wyczerpujący, zatem uchwalając regulamin czystości i porządku, rady gmin powinny zawrzeć w nim przepisy odnoszące się do wszystkich enumeratywnie wymienionych w ustawie zagadnień, nie mogą przy tym regulować kwestii, które wykraczają poza zakres wskazany w tym przepisie. Niedopuszczalne jest też dokonywanie wykładni rozszerzającej, pozwalającej na zastosowanie art. 4 ust. 2 ustawy do uregulowania innych kwestii, które nie zostały w nim wymienione ${ }^{24}$.

W sprawach dotyczących utrzymania czystości w gminach pojawiają się najczęściej nadużycia cenowe (przedsiębiorstwo komunalne świadczy usługi na rynku wywozu odpadów oraz ich składowania i decyduje o poziomie cen za składowanie odpadów) oraz narzucanie niekorzystnych warunków umów, na przykład odmowa zawarcia umowy przez gminne składowisko (należące do gminy), podczas gdy zezwolenie na prowadzenie działalności na terenie gminy uzależnione jest od dysponowania taką umową.

Decyzją z dnia 31 grudnia 2007 roku, RPZ-54/2007, Prezes UOKiK uznał za nadużywanie pozycji dominującej przez miasto Poznań ustalenie i stosowanie cennika za składowanie odpadów na składowisku miejskim w Suchym Lesie, przewidującego nieuzasadnione zróżnicowanie cen, co stwarza innym podmiotom zróżnicowane warunki konkurencji. Prezes UOKiK uznał również, że nieuzasadnione różnicowanie cen uprzywilejowuje jednego przedsiębiorcę, którego udziałowcem jest miasto Poznań. W toku postępowania ustalono, że na podstawie $\S 1$ pkt 1 uchwały nr XLVIII/568/III/2000 Rady Miasta Poznania z dnia 21 listopada 2000 roku w sprawie powierzenia Zarządowi Miasta Poznania uprawnień do ustalania niektórych cen i opłat, ceny pobierane za składowanie odpadów na składowisku miejskim ustala, w drodze zarządzeń, Prezydent Miasta Poznania, który wydawał odpowiednie zarządzenie przeciętnie raz w roku. Jak wynika z zarządzeń, kryterium różnicowania cen była ilość odpadów miesięcznie dostarczanych na wysypisko, przy czym przedsiębiorcą uprawnionym do uiszczania najniższych cen była spółka Remondis, w której ponad 49\% udziałów posiadało miasto Poznań. Prezes UOKiK powołał się przy tym na orzecznictwo Sądu Ochrony Konkurencji

23 M. Flek, [w:] Sąowa kontrola administracji w sprawach gospodarczych, red. A. Kisielewicz, J.P. Tarno, Warszawa 2013, s. 113.

24 Wyrok Wojewódzkiego Sądu Administracyjnego w Łodzi z dnia 21 października 2015 r., II SA/Łd 746/15, CBOSA. 
i Konsumentów, zgodnie z którym różnicowanie warunków działania przedsiębiorców w wyniku stosowania zróżnicowanych cen stanowi praktykę ograniczającą konkurencję ${ }^{25}$. Za stosowanie tych praktyk Prezes UOKiK nałożył na miasto Poznań karę pieniężną w wysokości 174534 zł. Prawidłowość decyzji potwierdziły zarówno Sąd Ochrony Konkurencji i Konsumentów, jak i Sąd Apelacyjny.

\subsubsection{RYNEK DOSTAW WODY I ODPROWADZANIA ŚCIEKÓW}

Rynek wodociągowo-kanalizacyjny jest szczególny, ponieważ przedsiębiorcy działają na nim w warunkach monopolu naturalnego, to jest pełnej dominacji bez jakichkolwiek konkurentów. Ta pozycja nie wynika z walki rynkowej, lecz z faktu, że do prowadzenia takiej działalności jest niezbędna infrastruktura, której specyfika nie pozwala na działalność kilku podmiotów gospodarczych. Koszty budowy sieci są tak duże, że w jednej gminie funkcjonuje tylko jedna sieć, a jej dublowanie albo zwielokrotnianie jest technicznie niewykonalne lub nieopłacalne; wszystkie koszty i tak spadłyby na odbiorców. Aby świadczyć wskazane usługi, konieczne jest bowiem dysponowanie odpowiednią infrastrukturą techniczną. Stwarza to istotną barierę kosztową w uruchomieniu działalności w tym zakresie ze względu na nieracjonalność budowy równoległej do istniejącej sieci wodociągowo-kanalizacyjnej. Z tych względów przedsiębiorstwa wodociągowo-kanalizacyjne działają w ramach monopolu naturalnego (monopolu sieciowego). Gospodarka wodno-kanalizacyjna prowadzona jest z reguły przez spółki gminne lub jest zorganizowana $\mathrm{w}$ formie zakładu budżetowego albo też gmina powierza wykonywanie tych zadań operatorowi prywatnemu.

Decyzją z dnia 30 grudnia 2014 roku, RKR-33/2014, Prezes UOKiK stwierdził nadużywanie przez gminę Rzezawa pozycji dominującej na lokalnym rynku zarządzania infrastrukturą wodociągowo-kanalizacyjną, między innymi uzależnianie przyłączenia do sieci od pokrycia kosztów budowy urządzeń od uczestnictwa w społecznym komitecie budowy sieci wodociągowo-kanalizacyjnej powołanym w ramach lokalnych inicjatyw inwestycyjnych i wpłatę z tego tytułu zryczałtowanej kwoty, nieodpowiadającej rzeczywistemu kosztowi budowy przyłącza. Społeczne komitety ds. budowy sieci kanalizacyjnej i wodociągowej były formalnie powoływane przez mieszkańców, ale sposób ich organizacji oraz zasady współuczestnictwa w realizacji budowy określono w uchwałach organów gminy, a więc w rzeczywistości powstawały one z jej inicjatywy. Gmina realizowała zadania z zakresu budowy sieci wodociągowo-kanalizacyjnej na podstawie uchwały z dnia 17 grudnia 2003 roku nr XI/76/03 w sprawie lokalnych inicjatyw inwestycyjnych. Uchwałą nr 53/2001 z dnia 31 grudnia 2001 roku. Zarząd Gminy Rzezawa ustalił wysokość opłaty pobieranej przez gminę w związku z przyłączeniem do sieci $(2500 \mathrm{zł})$. Prezes UOKiK uznał, że w tym przypadku warunki rozbudowy sieci były tylko pozornie dobrowolne. Pozorność występowała na dwóch etapach

25 Wyrok SOKiK z dnia 3 grudnia 2003 r., XVII Ama 139/02, „Wokanda” 2004, nr 11, poz. 50. 
- przy zawiązywaniu komitetów społecznych (ich powołanie określały władze gminy i był to w istocie przymusowy warunek, od którego uzależniano budowę sieci na danym obszarze), a zryczałtowana opłata (wynikająca także z odpowiednich regulacji gminnych) znacznie przewyższała koszty wybudowania przyłącza, pokrywała bowiem także część kosztów budowy sieci rozdzielczej i dokumentacji projektowej sieci. W związku z tym Prezes UOKiK uznał praktykę za nieuczciwą i uciążliwą oraz stwierdził, że gmina nadużyła pozycji dominującej. Za stosowanie tej praktyki Prezes UOKiK nałożył na gminę karę pieniężną w wysokości 17044 zł. Decyzja jest prawomocna.

\subsubsection{RYNEK TRANSPORTU LOKALNEGO}

Szczególne miejsce wśród zadań realizowanych przez każdą gminę zajmuje bieżące i nieprzerwane zaspokajanie zbiorowych potrzeb ludności. Ich wykonaniu służy świadczenie usług użyteczności publicznej, wśród których znajduje się organizowanie usług transportu zbiorowego. Naruszenia zasad wolnej konkurencji wywołują poważne skutki dla pasażerów korzystających z usług przewozu osób, a zatem zagadnienie to dotyczyć może znacznie szerszego kręgu osób niż tylko mieszkańców danej gminy (na przykład turystów korzystających z usług przewoźników lokalnych).

Decyzją z dnia 23 listopada 2016 roku, RLU-8/2016, Prezes UOKiK uznał za ograniczającą konkurencję praktykę gminy miejskiej Radzyń Podlaski, polegającą na nadużywaniu pozycji dominującej na lokalnym rynku udostępniania przystanków komunikacyjnych, przez odmowę udostępnienia przedsiębiorcom wykonującym krajowy transport drogowy przystanków komunikacyjnych będących własnością lub zarządzanych przez gminę miejską Radzyń Podlaski. Rozpatrując niniejszą sprawę, Prezes UOKiK trafnie wskazał na art. 15 ust. 1 pkt 6 ustawy o publicznym transporcie zbiorowym, zgodnie z którym organizowanie publicznego transportu zbiorowego polega między innymi na określaniu przystanków komunikacyjnych i dworców, których właścicielem lub zarządzającym jest jednostka samorządu terytorialnego, ust. 2 zaś tego przepisu wskazuje, że określenie przystanków komunikacyjnych i dworców oraz warunków i zasad korzystania, następuje w wyniku uchwały właściwego organu danej jednostki samorządu terytorialnego. Oznacza to, że gmina ma prawny monopol na podejmowanie działań związanych z wyznaczaniem przystanków oraz określaniu zasad korzystania z nich. Przepisy uchwały Rady Miasta Radzyń Podlaski nr VII/36 z dnia 31 marca 2011 roku w sprawie określenia przystanków komunikacyjnych i dworca na terenie miasta Radzyń Podlaski oraz warunków i zasad korzystania z nich określały wykaz przystanków, których właścicielem lub zarządcą jest gmina Radzyń Podlaski. Gmina podpisywała z przewoźnikami stosowne umowy cywilnoprawne i wskazywała im przystanki, z których mogą korzystać. Ten tryb wyrażania zgody na korzystanie z przystanków na terenie miasta obowiązywał wszystkich przewoź- 
ników, których linie komunikacyjne przebiegały przez granice administracyjne miasta. Gmina nie przedstawiała przedsiębiorcom żadnego uzasadnienia odmowy uzgodnienia korzystania z przystanków, a jedynie lakonicznie informowała o odmowie, bez wskazania możliwości ewentualnej modyfikacji wniosków.

Zdaniem Prezesa UOKiK miasto Radzyń Podlaski, wykorzystując te przepisy uchwały, arbitralnie decydowało, z którymi przewoźnikami zawierać umowy na korzystanie z infrastruktury będącej w zarządzie miasta (to jest przystanków komunikacyjnych). Przepisy uchwały mogły więc powodować zniekształcenie konkurencji, stąd też Prezes UOKiK uznał działania gminy miejskiej Radzyń Podlaski za praktykę ograniczającą konkurencję i nałożył karę pieniężną w wysokości 33 033,00 zł. Decyzja jest nieprawomocna.

\section{PODSUMOWANIE}

W społeczeństwie obywatelskim istotne znaczenie ma możliwość decydowania o sprawach lokalnych. Daje to jednostkom samorządu terytorialnego narzędzie skutecznego kreowania stosunków prawnych w obrębie danej wspólnoty mieszkańców. Jak wynika z przedstawionych uwag, akty prawa miejscowego mogą zawierać regulacje antykonkurencyjne. Stosowanie takich przepisów skutkować może dotkliwymi sankcjami finansowymi, które obciążają budżety gmin.

W literaturze przedmiotu nadal nie ma jednolitego stanowiska co do istoty aktów prawa miejscowego. Warto przypomnieć pogląd Z. Leońskiego, iż z istoty prawa miejscowego wynika, że powinno ono regulować swoiste właściwości „terenu”. Delegacje ustaw powinny zatem dawać radzie gminy określone „luzy”, albowiem to członkowie wspólnot samorządowych wiedzą najlepiej, jakie są ich potrzeby, a instytucje takie jak Sejm i Senat nie byłyby w stanie w sposób właściwy kreować stosunków panujących w społecznościach lokalnych. Uznając tę ideę za jedną $\mathrm{z}$ najważniejszych zasad w ramach decentralizacji państwa, powołano do życia niezależny samorząd terytorialny i nadano mu kompetencje do stanowienia prawa $^{26}$.

Pojawiają się też poglądy o potrzebie opracowania ustawy o zasadach i trybie wydawania aktów prawa miejscowego oraz ich kontroli, co zapewniłoby pełną realizację art. 94 Konstytucji. Ustawa umożliwiłaby wyeliminowanie istniejącego dotąd rozproszenia przepisów w kilku ustawach i ich nieuzasadnionego zróżnicowania. Pozwoliłaby też usystematyzować różnice między aktami samorządowymi i aktami administracji rządowej (na przykład dotyczące zasad sprawowania nadzoru $)^{27}$.

26 Z. Leoński, Samorząd terytorialny RP, Warszawa 2001, s. 40.

27 D. Dąbek, Prawo miejscowe, Warszawa 2007, s. 18. 
Interesujące wydają się też starania Polskiego Towarzystwa Legislacji, by kompleksowo uregulować status legislatora jako osoby odpowiedzialnej za redagowanie przepisów prawa w sposób jasny i precyzyjny oraz poprawny pod względem językowym, a tym samym zachowanie zgodności z systemem prawa oraz zasadami poprawnej legislacji. Instytucja taka byłaby też potrzebna $\mathrm{w}$ jednostkach samorządu terytorialnego.

Jak wynika z wskazanych przykładów, wadliwe akty prawne wydawane były przez duże jednostki władzy lokalnej, gdzie mieszczą się uznane ośrodki akademickie, a dostęp do wykwalifikowanych legislatorów był możliwy, i mniejsze gminne.

Sprawozdania roczne z działalności Prezesa UOKiK świadczą o systematycznym zmniejszaniu się liczby wydanych decyzji o uznaniu praktyk za ograniczające konkurencję i nakazujące ich zaniechania (w 2013 roku — dwadzieścia cztery decyzje, 2014 roku — dziewięć, 2015 roku - siedem) ${ }^{28}$. Do takiego stanu rzeczy przyczynia się niewątpliwie aktywna działalność edukacyjna nie tylko Prezesa UOKiK (publikowanie decyzji, wyroków, wyjaśnień, kampanie informacyjne ${ }^{29}$ ), lecz także orzecznictwo innych organów, choćby sądów administracyjnych ${ }^{30}$.

Znaczenie poprawnego stanowienia prawa wynika także ze stanowiska Trybunału Konstytucyjnego, zgodnie z którym z wyrażonej w art. 2 Konstytucji zasady państwa prawnego wynika nakaz przestrzegania zasad poprawnej legislacji ${ }^{31}$. Naruszeniem wymagań konstytucyjnych jest wadliwa, niedokładna i niejasna redakcja przepisu prawnego, która uniemożliwia precyzyjne ustalenie treści regulacji oraz powoduje niepewność jego adresatów co do praw i obowiązków. $Z$ zasady tej wynika nakaz formułowania przepisów prawa w sposób jasny i precyzyjny oraz poprawny pod względem językowym ${ }^{32}$. Trybunał Konstytucyjny dowodzi, że niejasne i nieprecyzyjne sformułowanie przepisu prawnego rodzi niepewność jego adresatów.

28 Sprawozdanie z działalności UOKiK za 2015 r., www.uokik.gov.pl.

29 Np. M. Czapliński, Poradnik wodociagowo-kanalizacyjny. Przegląd zagadnień w świetle decyzji UOKiK; P. Adamczewski, Świadczenie ushug cmentarnych i pogrzebowych, www.uokik.gov.pl.

30 Wskazać należy, że opracowany przez UOKiK poradnik dotyczący usług pogrzebowych i związane z nim działania promocyjne zostały docenione na forum międzynarodowym, w $2016 \mathrm{r}$. UOKiK otrzymał honorowe wyróżnienie na najlepszy projekt edukacyjno-informacyjny z dziedziny prawa konkurencji w konkursie Międzynarodowej Sieci Konkurencji (ICN) i Banku Światowego: „2015-2016 Competition Advocacy Contest: How to Build a Culture of Competition for Private Sector Development and Economic Growth".

31 Wyrok TK z dnia 7 stycznia 2004 r., sygn. K 14/03 (Dz.U. Nr 5, poz. 37); wyrok TK z dnia 27 kwietnia 2004 r., sygn. K 24/03 (Dz.U. Nr 109, poz. 1162).

32 Proces prawotwórczy w'świetle orzecznictwa Trybunatu Konstytucyjnego. Wypowiedzi Trybunału Konstytucyjnego dotyczace zagadnień zwiąanych z procesem legislacyjnym, opracowanie Biura Trybunału Konstytucyjnego, Warszawa 2015, s. 5. 


\title{
RULES RESTRICTING COMPETITION RESULTING FROM LOCAL LAW
}

\begin{abstract}
Summary
Pursuant to the Constitution of the Republic of Poland, territorial self-government bodies are authorized to issue local acts, i.a. concerning its own issues related to meeting the current needs of the inhabitants of the municipality, e.g. maintaining cleanliness, supplying water, organizing local transport. Due to the particular (monopolistic or dominant) position of the local self-government units, there are often violations of free market rules in these cases. The study presents typical cases of market abuse and distortions of free competition, originating in a defective local law - either because of a lack of compliance with the Protection of Competition and Consumers Act, or with another provision of generally applicable law such as the Act of Law on the maintenance of cleanliness and order in the municipalities. The consequences of such regulations are borne by consumers (inhabitants of municipalities) who have no choice - they suffer from severe (including financial) consequences of such defective regulations.
\end{abstract}

Keywords: local law, territorial self-government, restrictive practices, President of the Office of Competition and Consumer Protection, constitution, legislation

\section{BIBLIOGRAFIA}

Adamczewski P., Świadczenie usług cmentarnych i pogrzebowych, Warszawa 2014.

Bałaban A., Otwarty czy zamknięty system źródet prawa, [w:] Mała konstytucja w procesie przemian ustrojowych w Polsce, red. M. Kruk, Warszawa 1993.

Banasiński C., Piontek E., Ustawa o ochronie konkurencji i konsumentów. Komentarz, Warszawa 2009.

Boć J., Konstytucje Rzeczypospolitej oraz komentarz do Konstytucji RP z 1997 roku, Wrocław 1998.

Czapliński M., Poradnik wodociagowo-kanalizacyjny. Przegląd zagadnień w świetle decyzji UOKiK, Warszawa 2016.

Dąbek D., Prawo miejscowe, Warszawa 2007, 2015.

Dąbek D., Sądowa kontrola aktów prawa miejscowego - aspekt materialnoprawny, „Zeszyty Naukowe Sądownictwa Administracyjnego" 2013, nr 3.

Jurczyk Z., Zakres interwencji organu antymonopolowego $w$ działalność gospodarcza gmin, Warszawa 2011.

Konkurencja w gospodarce współczesnej, red. C. Banasiński, E. Stawicki, Warszawa 2007.

Kulesza M., Gospodarka komunalna — podstawy i mechanizmy prawne, „Samorząd Terytorialny” 2012, nr 7-8.

Leoński Z., Samorząd terytorialny RP, Warszawa 2001.

Mijal P., Cechy charakterystyczne aktów prawa miejscowego na tle orzecznictwa sądów administracyjnych, „Zeszyty Naukowe Sądownictwa Administracyjnego” 2007, nr 5-6.

Proces prawotwórczy w świetle orzecznictwa Trybunalu Konstytucyjnego. Wypowiedzi Trybunału Konstytucyjnego dotyczace zagadnień zwiazanych z procesem legislacyjnym, opracowanie Biura Trybunatu Konstytucyjnego, Warszawa 2015.

Sadowa kontrola administracji w sprawach gospodarczych, red. A. Kisielewicz, J.P. Tarno, Warszawa 2013.

Skoczny T., Dopuszczalność działalności gospodarczej gmin, „Samorząd Terytorialny” 1991, nr 3. 
Szreniawska M., System kontroli aktów prawa miejscowego, [w:] Samorząd terytorialny w Polsce a sadowa kontrola administracji, red. B. Dolnicki, J.P. Tarno, Warszawa 2012.

Szydło M., Monopol gminy w świetle regut funkcjonowania wspólnotowego rynku w Unii Europejskiej, „Samorząd Terytorialny” 2005, nr 7-8.

Świątkiewicz J., Prawo miejscowe pod rządem Konstytucji z 1997 r., „Przegląd Legislacyjny” $2000, \mathrm{nr} 1$.

Ustawa o samorzadzie gminnym. Komentarz, red. R. Hauser, Z. Niewiadomski, Warszawa 2014. 